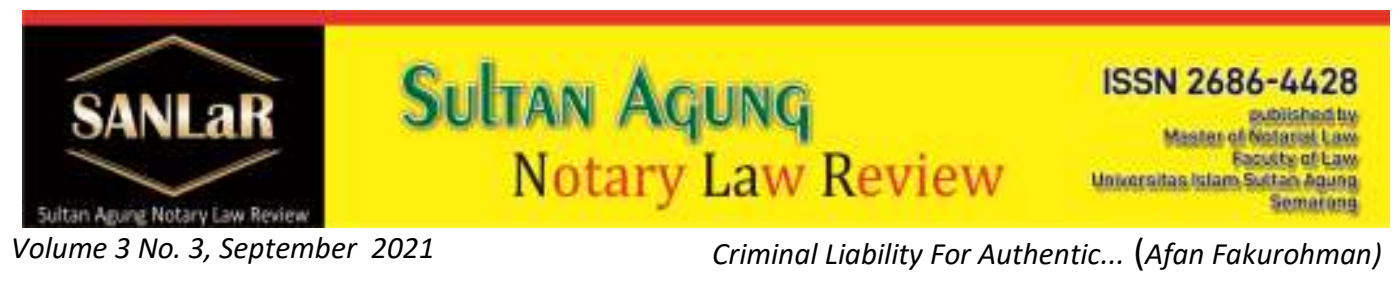

\title{
Criminal Liability For Authentic Deed Falsification By A Notary
}

\author{
Afan Fakurohman*) \\ *) Faculty of Law, Universitas Islam Sultan Agung (UNISSULA) Semarang, E-mail: \\ afan.billiejoe@gmail.com
}

\begin{abstract}
Notary is one of the public officials (openbaar ambtenar) who is authorized to make all kinds of agreements in the form of authentic deeds, set the date, keep the deeds and issue grosses, copies and quotations, all of this as long as the act of the deed is not also required to other officials. or specifically the obligation. However, it often happens that notaries do things outside their authority, one of which is committing a criminal act of falsifying authentic deeds which results in harming other parties so that this is very disturbing and must be handled either preventively or giving criminal sanctions. The method used in this research is normative juridical, the specification of this research is descriptive analytical research. The data source uses secondary data. Data collection techniques using literature study or document study. The data analysis technique used a qualitative descriptive approach. The results of the research on the first and second conclusions. In the case of falsification of an authentic deed which is very possible to be carried out by a notary person because the authentic deed which is the product is a deed that has perfect proof before the court and cannot be denied, but if the product of the notary in the form of an authentic deed contains things that are not true then the deed is degraded into a private deed and can be declared null and void by law.
\end{abstract}

Keywords : Notary; Authentic; Deed; Forgery.

\section{Introduction}

The Republic of Indonesia is a unitary state that has various ethnic groups, religions, cultures and languages, they are determined to unite to make the Indonesian state a strong and just state based on Pancasila and the 1945 Constitution so that justice and the rule of law are important elements in order to achieve the goals and ideals of the nation and state, in this case civil relations carried out by the community must be protected and have legal certainty in order to create a sense of security and justice for all elements of Indonesian society. 
Certainty and protection of the law must be clear so that it can be seen between the rights and obligations of a person as a legal subject in society, in terms of proof and certainty, it is very important the role of a notary as a security and guaranteeing legal certainty through an authentic deed he made which is expected to be a preventive effort in problems. disputes and problems

In the current context, more and more violations are found, both violations caused by violating the code of ethics and oath of office, which of course violates the rules in the Notary Position Act and violates Article 262 and Article 264 Paragraph (1) of the Criminal Code which results in violations. criminal acts committed by irresponsible notaries so that it is feared that this will damage the dignity and honor of the notary profession itself and the public is increasingly distrusting of the positions of public officials held by notaries because there are so many violations of fraud, forgery, collusion and so on. we must be swift in responding to this so that this incident does not drag on so that the dignity and honor of the profession can regain the trust of the community

The thing that underlies the birth of the Law on Notary Positions Number 30 of 2004 philosophically is the realization of a legal certainty, legal protection, legal order and has an impact on the creation of justice through the deed products made, several provisions in Act No. 30 of 2004 concerning the position of a notary is no longer in accordance with legal developments and needs so that changes are made with the existence of Act No. 2 of 2014 concerning amendments to Act No. 30 of 2004 concerning the position of a Notary which states that one of the authorities of a notary is to make an authentic deed regarding deeds, agreements and provisions required by legislation and or desired by interested parties who wish to be poured into an authentic deed,guarantee the certainty of the date, keep the deed, provide grosse, copies and quotations of the deed ${ }^{1}$.

With such great authority and responsibility, notaries are very vulnerable to abuse of authority, so in this case the author takes a case study of a notary named Adi Painem who has committed a crime of making fake letters or falsifying letters that can lead to rights, engagements or releases. debt, or is intended as evidence that something with the intent to use or order another person to use the letter as if the contents are true and not fake,this is tantamount to falsifying an authentic deed regulated in Article 264 Paragraph (1) subsidiary to Article 264 Paragraph (2) of the Criminal Code, thus the author will conduct a study entitled "Criminal Responsibility for Counterfeiting Authentic

\footnotetext{
${ }^{1}$ Nasution, Muhammad Syukri Albani, 2017, Hukum dalam Pendekatan Filsafat, Cetakan kedua, Jakarta: Kencana
} 
Deeds by a Notary (Case Study). Supreme Court Decision Number 1270 $\mathrm{K} / \mathrm{PID} / 2014)^{2}$.

\section{Research Methods}

The method used in this research is normative juridical, the specification of this research is descriptive analytical research. The data source uses secondary data. Data collection techniques using literature study or document study. The data analysis technique used a qualitative descriptive approach. The results of the research on the first and second conclusions.

\section{Result and Discussion}

Every profession in this world certainly has a code of ethics that is used for standards or norms that are applied and must be carried out by members, therefore as a notary must carry out his profession based on rules and codes of ethics so that justice can be created, based on the extraordinary congress of the Indonesian Notary Association held in Banten City 29-30 May 2015 mentions Article 3 point 4 explains that as long as a notary carries out his position, he is obliged to behave honestly, independently, impartially, trustworthy, thorough, full of responsibility that is in the notary code of ethics to apply things that must be carried out by a notary ${ }^{3}$.

The notary as a public official with the authority to make an authentic deed is also charged with keeping the protocol, this is in accordance with Article 1 Number 13 of the Notary Position Law which states that the notary protocol is a collection of documents which are state archives that must be copied and maintained by the notary concerned. ${ }^{4}$ In addition, in carrying out his position, the notary is obliged to be professional and impartial and has good integrity in carrying out his position in producing authentic deeds.

An authentic deed is a deed made before an authorized official which is a perfect piece of evidence unless the claimant party can prove another which means that the deed is absolutely perfect in what it contains and binds the parties who bind themselves to the deed or have legal consequences. for the parties in the deed and if it enters the realm of the court, the burden of proof is imposed

\footnotetext{
${ }^{2}$ R, Putri A., 2011, Perlindungan Hukum Terhadap Notaris Indikator Tugas-Tugas Jabatan Notaris yang Berimplikasi Perbuatan Pidana, Jakarta: PT.Sof

${ }^{3}$ Ibid.

${ }^{4}$ A Chuasanga, Ong Argo Victoria. (2019). Legal Principles Under Criminal Law in Indonesia Dan Thailand, Jurnal Daulat Hukum, Vol 2, No 1 (2019) http://jurnal.unissula.ac.id/index.php/RH/article/view/4218
} 
The formal aspect, if disputed by the parties, must be proven by the formality of the deed, that is, it must be able to prove the absence of the day, date, month, year and time of presentation. The best evidence to refute the formal aspects of a notarial deed. If you are unable to prove the untruth, the deed must be accepted by anyone.

The contents of the notary deed have the correct certainty so that it becomes valid evidence for the parties interested in it, if the proof is the material aspect of the deed, the person concerned must be able to prove that the notary or the opposing party did not explain or state the truth in the deed, this makes the proof reversed. and if there is an indication that the notary has from the start intentionally committed a criminal act by committing forgery as if what is in the deed is genuine and true. Violations in making an authentic deed committed by a notary will make the notary face to face with law enforcement as experienced by a notary ADI PAINEM, SH notary in Deli Serdang district who has been proven conclusively guilty of committing the crime of forging authentic deeds as regulated in the Book of Law.

The crime in Article 264 paragraph (1) which has permanent legal force through the cassation decision as stated in Decision Number 1270K/PID/2014 with the incident which the author describes as follows. The case that occurred in Medan was carried out by a notary named Adi Painem, SH, an Indonesian citizen who was born on March 13, 1963 who works as a notary who lives on Jalan Pasar Baru No. 1A Delitua, Delitua District, Deliserang Regency.

In chronology the author describes as follows that on Wednesday, July 10, 2002 at the notary office of Adi Painem at Jalan Kolonel Sugiono Number 18B, Medan City which is the jurisdiction of the Medan District Court, he has made a false letter or falsified a letter that gives rise to a right, engagement or debt relief, or which is intended as evidence of something with the intention of using or ordering someone else to use the letter as if its contents were new or not fake, such use causes losses because the forgery of the letter is contained in the authentic deed ${ }^{5}$.

On Wednesday 10 July 2002, the defendant Efrata Ngerajai Ginting and the defendant Syafrin Sitepu went to the defendant at the notary Adi Painem's office, which is located at Jalan Kolonel Sugiono Number 18B, Medan city to make a deed of relinquishing land rights with compensation, then the defendant Adi Painem asked for the identity of the defendant. Syarif Sitepu and the defendant Efrata Ngrajai Ginting along with a photocopy of the rights to the

\footnotetext{
${ }^{5}$ Deen, Thaufiq., Ong Argo Victoria \& Sumain. (2018). Public Notary Services In Malaysia. JURNAL AKTA: Vol. 5, No. 4, 1017-1026. Retrieved from http://jurnal.unissula.ac.id/index.php/akta/article/view/4135
} 
object being compensated in the form of an underhand certificate dated April 28, 1956 and a certificate of land registration number 157/II/SKPT/1967 dated April 18, 1967 where in the picture the dimensions and dimensions are complete. land boundaries,After that the defendant notary Adi Painem read the photocopy of the certificate under the hand then immediately made a deed of relinquishing land rights with compensation number 24 after the deed was typed the defendant notary Adi Painem read the deed then signed the defendant Syarif Sitepu and the defendant Efrata Ngarajai Ginting along with the defendant notary Adi Painem 6 .

Whereas in the deed of relinquishment of land rights with compensation number 24 there are several information that is not in accordance with the conditions in the field and supporting data, namely located in the comparison of the deed which states that is in the form of being the only heir of the late Ndjajan Sitepu who has died in Medan. on December 17, 1975 and the late Saodah Beru Meliala who died in Medan on February 25, 1968 which, according to the testimony of the witness, is based on the original heirs certificate dated April 5, 2002 number 474/095 issued by the Camat of Percut Sei Tuan Subdistrict, the original shown to the notary Adi Painem.

Based on the testimony of the defendant Syarif Sitepu that the heirs of the late Djajam Sitepu were not only the defendant Syafri Sitepu but there were 13 other people from the first 3 marriages who married the late Rukiyah and had 3 children namely the late Marsini, the late Rolia and Asna. Then Djajam Sitepu remarried to the late Saodah and gave birth to 8 children, namely the late Surya Sitepu, Rosni Sitepu, Sukarman Sitepu, Herawati Sitepu, Sofyan Sitepu, the defendants Syarif Sitepu, Sunandi Sitepu and Susanti Sitepu. Then Djajam Sitepu married for the third time with Sumpena Meliala and had 2 children namely Agus Salim Sitepu and Efrika Sitepu.

Then in the premise of the deed that outlines the boundaries of the land, namely a plot of vacant land covering an area of approximately 8,317 square meters located in the province of North Sumatra, Medan City, Medan Baru District, Titirante Village which has northern boundaries bordering the trumpet road along the 70 meters, to the south it is bordered by a 108.5 meter long fiddle road, to the east it is bordered by a 70 meter long road, to the west it is bordered by a 108 meter long road.and planted on the land according to its nature and provisions according to the law, including in its field and the land is based on an underhand certificate with sufficient stamp duty dated 28 April 1956 issued by the head of the land affairs officer of the Medan City and related to the land

\footnotetext{
${ }^{6}$ Anshori, Abdul Ghofur, 2009, Lembaga Kenotariatan Indonesia Prespektif Hukum dan Etika, Cetakan Pertama, Yogyakarta: UII Press, see too Atmasasmita, Romli, 2001, Reformasi Hukum dan Hak Asasi Manusia dan Penegakan Hukum, Bandung: Mandar Maju
} 
registration certificate dated 18 April 1967 with the number 157/II/SKPT/SDA/1967 issued by the head of the land registration and supervision office which has been shown to the defendant notary Adi Painem.

Based on the agreement between the defendant Syafrin Sitepu and the defendant Efrata Ginting that the agreed compensation was 60 million rupiah and had been paid by the defendant Efrata Ginting and had been received with the defendant Syafrin Sitepu before the deed of relinquishing land rights with compensation number 24 was signed later that the deed relinquished the rights on land with compensation number 24 dated July 10, 2012 which was made before the defendant Adi painem Efrata Ngarajei Ginting immediately returned home then the deed was used by the defendant Efrata Ginting to file a lawsuit against the Medan city government, the Sumatra Provincial BPN Regional Office, and the Medan City Land Office in accordance with decision number 05/Pdt.G/2005PN.Mdn, Angel February 2 2006, and the decision of the Supreme Court of the Republic of Indonesia Number 1831.K.Pdt/2007 dated March 17, 2009 as well as a review of the Supreme Court of the Republic of Indonesia number 59-PK/PDT/2011 dated November 29, which was entirely won by the defendant Efrata Maraja Ginting then the defendant requested execution to the Medan District Court in accordance with the letter of determination Number 19/Ex /2010/05/Pdt.G/2005/PN.Mdn dated April 28, 2010 however, the execution has not been carried out until now according to the statement from the Medan District Court to the defendant Efrata Ginting that the execution of the land could not be carried out because the situation was not conducive .Mdn dated April 28, 2010 but the execution has not been carried out until now according to the statement from the Medan District Court to the defendant Efrata Ginting that the execution of the land has not been carried out because the situation has not been conducive.Mdn dated April 28, 2010 but the execution has not been carried out until now according to the statement from the Medan District Court to the defendant Efrata Ginting that the execution of the land has not been carried out because the situation has not been conducive.

But in reality in the field on the land that will be executed there has been a Batak Karo Protestant church Pasar 2 Tili Chain Jalan rebab number 54 Padang Bulan, the Batak Karo Protestant church has a right of title in the form of a certificate of ownership rights number 367 Kelurahan Titi chain, Medan Baru District, Medan city dated May 6, 2004 covering an area of 1748 M2 under the name of the right holder of the Batak Karo Protestant church domiciled in Kabanjahe in the title certificate number 367 which is described in the instructions that the former right of use number 8 Desa Hilir Amuntai dated April 1, 1982 covering an area of $10762 \mathrm{M} 2$ in the name of the right holder of the Batak Karo church Protestant based in Kabanjahe.and that as a result of the execution plan, the Batak Karo Protestant church in the Tili Chain Padang Bulan market felt very disadvantaged 
because the assets of the Batak Karo Protestant church were executed in an area of 1162 M2. Later, the management of the Batak Karo Protestant Church through their legal advisor, witness Ukur Muli Sebayang, reported this to the North Sumatra regional police for further processing.

The defendant, Adi Pinem, on Wednesday 10 July 2002 at the notary's office, Jalan Kolonel Sugiono No. 18 B, Medan city, which is part of the Medan District Court, deliberately used a fake letter in the form of an authentic deed whose contents were falsified and pretended to be true or not fake. After that, the Medan State Prosecutor's Office on April 292014 demanded that the defendant Adi Painem after being proven guilty of committing a criminal act of making a fake letter or falsifying a letter that could give rise to a right, engagement or debt relief or which was intended as evidence of something with the intention of use or order another person to use the letter as if the contents are true and not fake if such use can cause harm to an-naba using the letter,against the authentic deed as charged, namely violating Article 264 Paragraph (1) of the Criminal Code in the primary charge of imposing a sentence on the defendant Adi Painem with a prison sentence of 2 years and 6 months.

In this case, the public prosecutor disclosed some evidence including a photocopy of the minutes of deed of relinquishment of land rights with compensation number 24 dated July 10, 2002 which was legalized by the Medan district court then a photocopy of certificate number 129/1952 dated April 25, 1952 in the name of Djajam Sitepu who legalized by the Medan district court then a photocopy of the decision of the PN case Number 05/PDT/2006/PN.MDNT dated February 2, 2006, then the decision of PT 150/PDT/2006/PT-MDN dated December 15, 2006, the decision of the Supreme Court Number 1831.Kpd/2007 dated March 17, 2009 and the determination of execution Number 19/Eks/2010/05/Pdt.G/2005/PN.MDN On April 28, 2010 which was legalized by the Medan District Court then determined that the defendant was burdened with paying court fees of IDR 1,000.

Then in the Medan District Court Decision Number 2527/Pid.B/2013/PN.Mdn dated June 17, 2014, the verdict stated that the defendant Adi Painem was not legally and convincingly proven guilty of committing a criminal act as charged by the public prosecutor and then acquitted the defendant. therefore from all kinds of indictments and recovering the rights of the accused in terms of his position and dignity and imposing court costs on the state ${ }^{7}$.

Criminal cases granted at the last level by a court other than the Supreme Court, the defendant or the public prosecutor may submit a request for cassation to the Supreme Court except for an acquittal, but that the Supreme Court is of the

${ }^{7}$ Chazawi, Adami, 2008, Pelajaran Hukum Pidana Bagian I, Jakarta: PT.Raja Grafindo 
opinion that apart from the highest judicial body which has the duty to foster and maintain all laws and laws throughout the territory of the Unitary State of the Republic of Indonesia. then the Supreme Court is not authorized to examine the cassation request against the acquittal.

The reasons used by the public prosecutor to file an appeal explained that the panel of judges at the Medan district court in examining and adjudicating the case had made a mistake, among others, that a legal regulation was not applied or not applied properly, namely related to the articles charged against the defendant. painem, namely the primary article 264 paragraph 11 of the criminal law code, subsidiary article 264 paragraph 2 of the criminal law code, are the articles in the criminal law code which are included in what is considered fully implemented by committing an act that it is prohibited that in the consideration of the panel of judges there are elements of forgery of authentic deeds contained in article 262 paragraph 11 of the criminal law code have been fulfilled and that the type offormal consequences arising from an action is not the main thing because what is prohibited is the action, because the defendant's actions have fulfilled the elements of article 264 paragraph 11 of the criminal law code as indicted by the public prosecutor in the primary indictment, the defendant must be declared legally and convincingly guilty of committing an act of deed forgery. Therefore, before imposing a sentence on the Court The Supreme Court will consider the aggravating and mitigating factors for the defendant. Among the aggravating factors is that it is inappropriate for a notary to do this, while the mitigating factors for the defendant are that the defendant has never been sentenced ${ }^{8}$.

Then instead of the things that have been described by the public prosecutor, the Supreme Court will make considerations so that a fair decision occurs which in the decision adjudicates the cassation request from the public prosecutor of the Medan District Attorney and cancels the Medan District Court Decision Number 2527/ Pid.B/2013/PN.Mdn dated June 17, 2014 then tried himself, stating that the defendant Akifa Inem was legally and convincingly proven guilty of committing the crime of falsifying an authentic deed and sentenced the defendant in Adi Painem to 6 months in prison.

This makes it an important note to all notaries in Indonesia that in carrying out their duties and functions as public officials, they must comply with the rules and laws and regulations so that mistakes do not occur and result in harm to themselves and others. in carrying out his position regarding the making of an authentic deed because it will have legal consequences for the parties concerned. The imposition of criminal sanctions against a Notary who commits a

\footnotetext{
8 Machmudin, Dudu Duswara, 2003, Pengantar Ilmu Hukum Sebuah Sketsa, Bandung: Refika Aditama and Marzuki, Peter Mahmud,2010.Penelitian Hukum, Ed. 1, print. IV, Jakarta: Kencana
} 
crime can be carried out as long as the formulation of the violation contained in the law is fulfilled.

\section{Closing}

The responsibility of a notary who commits a crime of deed falsification is as regulated in the provisions of Article 264 paragraph 1 of the Criminal Code concerning the falsification of authentic deeds, namely falsification of letters, threatened with imprisonment for a maximum of 8 years, if committed against: authentic deeds, debt securities or certificate of debt from a country or part or from a public institution, demand deposit or debt or demand deposit certificate or debt from an association, foundation, company or airline, talon, proof of dividend or interest from one of the letters described in 2 and 3 or proof issued in lieu of the letters, letters of credit or trade letters intended to be circulated.

\section{References}

Journals:

[1] A Chuasanga, Ong Argo Victoria. (2019). Legal Principles Under Criminal Law in Indonesia Dan Thailand, Jurnal Daulat Hukum, Vol 2, No 1 (2019) http://jurnal.unissula.ac.id/index.php/RH/article/view/4218

[2] Deen, Thaufiq., Ong Argo Victoria \& Sumain. (2018). Public Notary Services In Malaysia. JURNAL AKTA: Vol. 5, No. 4, 1017-1026. Retrieved from http://jurnal.unissula.ac.id/index.php/akta/article/view/4135

Books:

[1] Anshori, Abdul Ghofur, 2009, Lembaga Kenotariatan Indonesia Prespektif Hukum dan Etika, Cetakan Pertama, Yogyakarta: UII Press

[2] Atmasasmita, Romli, 2001, Reformasi Hukum dan Hak Asasi Manusia dan Penegakan Hukum, Bandung: Mandar Maju

[3] Chazawi, Adami, 2008, Pelajaran Hukum Pidana Bagian I, Jakarta: PT.Raja Grafindo

[4] Machmudin, Dudu Duswara, 2003, Pengantar Ilmu Hukum Sebuah Sketsa, Bandung: Refika Aditama

[5] Marzuki, Peter Mahmud,2010.Penelitian Hukum, Edisi ke-1 Cet IV, Jakarta: Kencana

[6] Muhammad, Abdulkadir,2001, Etika Profesi Hukum,Bandung: Citra Aditya Bhakti

[7] Nasution, Muhammad Syukri Albani, 2017, Hukum dalam Pendekatan Filsafat, Cetakan kedua, Jakarta: Kencana 
[8] R, Putri A., 2011, Perlindungan Hukum Terhadap Notaris Indikator TugasTugas Jabatan Notaris yang Berimplikasi Perbuatan Pidana, Jakarta: PT.Sof 